\title{
Realizacja zasady pomocniczości w normach prawnych ustawodawstwa ukraińskiego dotyczących rodziny i dzieci
}

Jedną z głównych zasad społecznej doktryny Kościoła katolickiego oraz współczesnej praktyki budowania systemu relacji w strukturach społecznych jest zasada pomocniczości. Ta zasada oparta jest na koncepcji: (a) rozdzielenia i wzmocnienia pełnomocnictw pomiędzy różnymi poziomami struktur i instytucji socjalnych i (b) pomocy ze strony struktur poziomu wyższego dla struktur poziomu niższego wtedy, kiedy te ostatnie nie są w stanie wykonać swojego pełnomocnictwa.

Główny akcent w zasadzie pomocniczości spoczywa właśnie na pomocy ze strony struktur poziomu wyższego dla struktur poziomu niższego zamiast brania na siebie wszystkich pełnomocnictw. Tak mówi o tym Katechizm Kościoła katolickiego: „pomocniczości, rozumianej w znaczeniu pozytywnym jako pomoc ekonomiczna, instytucjonalna, legislacyjna oferowana najmniejszym komórkom społecznym, odpowiada cały szereg negatywnych konsekwencji, które narzucają państwu obowiązek powstrzymania się od tego, co 
faktycznie ograniczałoby przestrzeń życiową najmniejszych i najbardziej znaczących komórek społecznych. Ich inicjatywa, wolność i odpowiedzialność nie mogą być w żaden sposób podważane” (p. 186)1.

Z praktycznego punktu widzenia zasada ta oznacza także, że w strukturze społecznej należy rozróżniać hierarchię składającą się z:

(a) wspólnot poziomu podstawowego - na przykład małżeństwa i rodziny, parafii, lokalnych wspólnot etc.;

(b) wspólnot pośrednich albo struktur pośrednich - na przykład zjednoczenia obywateli, partii, związków etc.;

(c) wspólnot poziomu wyższego - na przykład państwa.

Utrzymanie tej zasady pozwala na zabezpieczenie optymalnego rozwoju osoby i małych wspólnot (rodziny, różnych stowarzyszeń, organizacji religijnych etc.) oraz wpływa na pogłębianie odpowiedzialności wspólnot podstawowych i struktur pośrednich za życie społeczne. Przy tym ważne jest to, że „z zasadą pomocniczości kontrastują rozmaite formy centralizacji, biurokracji, opiekuńczości, nieuprawnionej i przesadnej obecności państwa i władz publicznych w życiu społecznym [...]. Urzeczywistnieniu zasady pomocniczości odpowiadają: poszanowanie i rzeczywiste popieranie prymatu osoby i rodziny; docenianie znaczenia stowarzyszeń i organizacji pośrednich, wspieranie ich w podejmowaniu własnych, istotnych decyzji i w dokonywaniu wyborów, które nie mogą być przerzucane na innych ani przez nich podejmowane; zachęta kierowana w stronę prywatnej inicjatywy powinna być w taki sposób, aby każdy organizm społeczny, z charakterystycznymi dla niego właściwościami, służył dobru wspólnemu; pluralistyczny podział społeczeństwa i przedstawicielstwo ożywiających

1 Kompendium nauki społecznej Kościoła, www.vatican.va/roman_curia/ pontifical_councils/justpeace/documents/rc_pc_justpeace_doc_20060526_compendio-dott-soc_pl.html (14.01.2015). 
go sił; poszanowanie praw człowieka i mniejszości; decentralizacja biurokracji i administracji; równowaga między sferą publiczną i prywatną, z wynikającym stąd uznaniem społecznej roli własności prywatnej; przyznanie adekwatnej odpowiedzialności obywatelowi, będącemu aktywną «cząstką» rzeczywistości politycznej i społecznej kraju" (p. 187)2.

Wprowadzenie i dotrzymanie zasady pomocniczości jest niezwykle ważne dla systemu prawnego Ukrainy, ponieważ w latach 1991-2013 w państwie ukształtowała się zdeformowana struktura socjalna paternalistycznego typu, charakteryzująca się skupieniem pełnomocnictw i środków w rękach centralnego urzędu oraz odpowiednim do tego ograniczaniem pełnomocnictw i środków przysługujących społecznościom podstawowego i pośredniego poziomu. Ponadto zasada ta jest ważna również ze względu na status prawny rodziny i dziecka, ponieważ chodzi o to, jaki właściwie status prawny - przedmiotowy czy podmiotowy - będzie nadawało ustawodawstwo ukraińskie rodzinie jako wspólnocie poziomu podstawowego.

Celem niniejszego artykułu jest: (a) analiza głównych aktów normatywnych korpusu czynnego ustawodawstwa Ukrainy, a mianowicie: konstytucji, kodeksów rodzinnego, cywilnego, postępowania cywilnego, karnego, postępowania karnego, podatkowego oraz ich zgodności z zasadą pomocniczości w sensie, o którym była mowa powyżej, oraz: (b) określenie gotowości ukraińskiego systemu prawnego do wykorzystania tej zasady w praktyce prawnej.

\section{Analiza czynnego ustawodawstwa Ukrainy}

Na płaszczyźnie prawnej problem zasady pomocniczości naszym zdaniem będzie powiązany z pytaniem, do którego poziomu będą odnosiły się normy prawne - publiczno-prawnego czy prywatno-prawnego,

2 Kompendium nauki społecznej Kościoła. 
jak o tym mówił Ulpian: „Publicum ius est quod ad statum rei Romanae spectat, privatum quod ad singulorum utilitatem: sunt enim quaedam publice utilia, quaedam privatim" (Dig. 1.1.1.2)3. Dlatego też nasze badania będziemy przeprowadzać, analizując dokumenty publiczno-prawne (kodeks postępowania cywilnego, karny, postępowania karnego, podatkowy) oraz prywatno-prawne (kodeks rodzinny, cywilny) akty normatywne prawodawstwa Ukrainy.

Definicja „pomocniczości” nie jest charakterystyczna dla ustawodawstwa Ukrainy. Faktycznie jedynym normatywno-prawnym aktem, gdzie ona występuje, jest Kodeks budżetowy Ukrainy: „Zasada pomocniczości - podział rodzajów wydatków między państwowym budżetem i miejscowymi budżetami, a także między miejscowymi budżetami opiera się na konieczności możliwie maksymalnego zapewnienia gwarantowanych usług ich bezpośredniemu konsumentowi” (art. 7 KBU) ${ }^{4}$. Ta definicja praktycznie jest identyczna z definicją Europejskiej Karty Samorządu Lokalnego: ,zadania publiczne powinny być realizowane na jak najniższym szczeblu przy zapewnieniu środków proporcjonalnych do osiągnięcia zamierzonego celu. $\mathrm{W}$ tym sensie samorząd terytorialny w nowoczesnym państwie powinien odgrywać podstawową rolę w systemie administracji publicznej”. Dlatego uważamy, że defi-

3 Дигесты Юстиниана (Digesta Justyniana), t. 1: Кн. 1-4 / Отв. ред.: Л.Л. Кофанов, Москва 2002, s. 584.

4 Бюджетний кодекс України (Kodeks budżetowy Ukrainy) (Редакція від 26.10.2014) / Закон від 8 липня 2010 року, № 2456-VI, „Відомості Верховної Ради України” від 24.12.2010 - 2010 р., № 50, / № 50-51/, ст. 1778 (із змінами та доповненнями).

5 Europejska Karta Samorządu Terytorialnego, sporządzona w Strasburgu 15.10.1985 r., Dz.U. 1994 nr 124 poz. 6o7, http://isap.sejm.gov.pl/DetailsServlet?id=WDU19941240607 (14.01.2015). 
nicję „pomocniczości” w tym wypadku można interpretować nie w takim kontekście, jak rozumie to katolicka doktryna społeczna, ale w kontekście próby adaptacji ustawodawstwa ukraińskiego do europejskiego. W innych tekstach ukraińskich aktów prawnych definicja ta nie występuje.

\section{Zasada pomocniczości odnośnie do dzieci i rodziny w Konstytucji Ukrainy}

Normy Konstytucji Ukrainy ${ }^{6}$ nie zawierają definicji „pomocniczości”, podobnie jak ustawodawstwo, które od nich pochodzi. Zresztą w rozdziale II Prawa, wolności i obowiązki człowieka i obywatela można znaleźć formuły prawne, które pozwalają w ten czy inny sposób zinterpretować je jako podstawę dla pomocniczego rozumienia ukraińskiego prawa. Na przykład, art. 32 stwierdza, że nikt nie może doświadczać ingerencji w jego osobiste i rodzinne życie. Ale warto zwrócić uwagę na zastrzeżenie zawarte w tym artykule: „oprócz wypadków przewidzianych Konstytucją Ukrainy”. Art. 46 określa prawo obywateli do korzystania z pomocy społecznej. Ważne jest to, że owo prawo nie ma charakteru bezwarunkowego, ale stanowi o prawie do zabezpieczenia w takich przypadkach, jak na przykład strata żywiciela, bezrobocie z niezależnych od poszkodowanego przyczyn oraz w innych wypadkach przewidzianych ustawodawstwem.

W kontekście naszego studium ważny wydaje się art. 51, który stanowi, że właśnie rodzice są zobowiązani utrzymywać dzieci do ich pełnoletności, a pełnoletnie dzieci mają obowiązek troszczyć się o swoich niezdolnych do pracy rodziców. Jednak w razie straty rodziców z tych czy innych powodów konstytucja podaje artykuł 52, według

6 Конституція України (Konstytucja Ukrainy): чинне законодавство зі змінами та доповненнями станом на 24 листопада 2014 р.: (офіційний текст), Київ 2014, с. 64. 
którego do utrzymania i wychowania dzieci-sierot i dzieci pozbawionych opieki rodzicielskiej zobowiązane jest państwo, które jednak tylko „zachęca i podtrzymuje działalność dobroczynną względem dzieci”.

W ten sposób możemy konstatować, że część norm Konstytucji zakłada podstawę dla realizacji zasady pomocniczości odnośnie do obrony praw rodziny i dziecka (art. 32, 46, 51). Jednak część przepisów prawnych obdarza odpowiednimi uprawnieniami państwo, omijając wspólnoty poziomu podstawowego czy struktury pośrednie (art. 52), tym samym przekreślając potencjalne pozytywne skutki omówionych powyżej norm.

\section{Zasada pomocniczości odnośnie do dzieci i rodziny w Kodeksie rodzinnym Ukrainy}

We współczesnym społeczeństwie instytucja małżeństwa i rodziny potrzebuje szczególnej uwagi i wsparcia ze strony całego narodu. Jak podkreślał Dietrich von Hildebrand, badając różne rodzaje i formy wspólnot ludzkich w społeczeństwie: „Fundamentalna jest różnica między formalną i treściową wspólnotą. Małżeństwo jest wspólnotą jednocześnie treściową i formalną. Państwo - to wspólnota formalna; naród - treściowa [...]. Odnośnie do znaczenia, które ma wspólnota małżeńska dla ujawnienia wartości w człowieku, już sama jej treść i sens pokazują, że jest ona w tym znaczeniu o wiele wyższa niż wszystkie inne rodzaje wspólnot"7. Ta sama idea jest obecna w normach Kodeksu rodzinnego Ukrainy (KRU) ${ }^{8}$, które pozwalają podjąć kwestie uwzględnienia

7 Д. фон Гильдебранд, Метафизика коммуникации (Metafizyka wspólnot), Санкт-Петербург 200о, с. 373, 194, 328

8 Сімейний кодекс України (Kodeks rodzinny Ukrainy) від 1 о січня 2002 p. № 2947-III, „Відомості Верховної Ради України (ВВР)”, 2002 р., № 21-22, ст. 135 (із змінами та доповненнями). 
samodzielności finansowej wspólnot treściowych przez prawne wsparcie instytucji małżeństwa i rodziny. Odpowiednio do art. 3 KRU rodzina jest pierwotnym i głównym ośrodkiem społeczeństwa. Kodeks określa, że żona i mąż powinni materialnie wspierać się nawzajem (art. $75 \mathrm{KRU}$ ), a także przypomina o zobowiązaniu rodziców do utrzymywania dziecka aż do osiągnięcia przez nie pełnoletności (art. 18o KRU). Przy tym małżeństwo nabywa prawa współwłasności łącznej co do majątku nabytego w trakcie trwania małżeństwa, który należy się żonie i mężu niezależnie od tego, że jedno z nich mogło z poważnego powodu (pobieranie nauki, prowadzenie gospodarstwa domowego, opieka nad dziećmi, choroba itp.) nie uzyskać samodzielnego zarobku albo dochodu (art. 6o KRU).

Według kodeksu przedmiotem prawa współwłasności łącznej jest wynagrodzenie, emerytura, stypendium oraz inne dochody otrzymane przez jednego z małżonków i wniesione do rodzinnego budżetu albo wniesione na jego osobisty rachunek bankowy (art. 61 KRU). W taki sposób Kodeks rodzinny Ukrainy stwarza dosyć jednoznaczną prawną przestrzeń dla ochrony interesów rodziny i małżeństwa z uwzględnieniem osobliwości stanu rodzinnego podatników. Jak słusznie podkreśla Dietrich Brümmerhoff, w ostatecznym rachunku uwzględnienie stanu rodzinnego podatnika przy opodatkowaniu zależne jest przede wszystkim od wartości społecznych, gdzie wartością nadrzędną jest wzięcie pod uwagę roli rodziny w społeczeństwie 9 .

Na ogół normy co do realizacji zasady pomocniczości w Kodeksie rodzinnym Ukrainy znajdują się w rozdziale III - Prawa i obowiązki matki, ojca i dziecka. W szczególności rozdział 13 mieści

9 Д. Брюммерхофф, Теория государственных финансов (Teoria finansów publicznych), Владикавказ 2001, s. 480, 262. 
listę niemajątkowych praw i obowiązków rodziców i dzieci, wśród których w kontekście naszej analizy warto wspomnieć:

- obowiązek rodziców odebrania dziecka ze szpitala położniczego albo innego zakładu lecznictwa (art. $143 \mathrm{KRU);}$

- obowiązek rodziców wychowywania i wspierania rozwoju dziecka (art. 150 KRU);

- pierwszeństwo prawa rodziców do osobistego wychowania dziecka przed innymi osobami (p.1 art. $151 \mathrm{KRU}$ );

- prawo rodziców do samoobrony (sic!) swojego dziecka, pełnoletnich córki i syna (p. 1 art. 154 KRU);

- pierwszeństwo prawa rodziców wobec innych osób do zamieszkania małoletniego dziecka z nimi (p. 1 art. 163 KRU) itp.

Ważne normy prawne zawiera art. $167 \mathrm{KRU}$ w odniesieniu do hierarchizacji ewentualnych miejsc zamieszkiwania dziecka w przypadku, gdy jego rodzice są pozbawieni praw rodzicielskich. Według p. 4 art. 167 KRU w podobnych sytuacjach, jeśli dziecko nie może być oddane drugiemu z rodziców, pierwszeństwo przed innymi osobami w sprawowaniui opieki nad dzieckiem mają: babcia i dziadek, pełnoletni bracia i siostry, inni krewni dziecka, macocha, ojczym. Tylko wtedy, kiedy wymogi p. 4 art. 167 nie mogą być wykonane, ma zastosowanie norma o przekazaniu dziecka pod opiekę państwowemu organowi opieki i kurateli (p. 5 art. 167 KRU).

Co do zasady pomocniczości w prawach majątkowych ważne miejsce w Kodeksie rodzinnym Ukrainy ma rozdział 15: Obowiązkiem matki, ojca jest utrzymanie dziecka i wykonanie tego obowiq̨z$k u$, oraz rozdział 16 Obowiq̨zek rodziców utrzymywania petnoletniej córki, syna i jego wykonanie i ich lustrzane odbicie - rozdział 17 Obowiq̨zek petnoletniej córki i syna utrzymywania rodziców i jego wykonanie. Jak wynika już z samych nazw rozdziałów, ustawodawstwo ukraińskie przez pewne procedury obowiązuje jednych członków rodziny do utrzymywania innych członków rodziny, między innymi: 
(a) rodzice są zobowiązani utrzymywać dziecko do osiągnięcia przez niego pełnoletności (art. 18o KRU);

(b) rodzice są zobowiązani utrzymywać swoje pełnoletnie dzieci, jeśli są one niezdolne do pracy: córkę, syna, którzy potrzebują materialnej pomocy, jeżeli mogą oni taką materialną pomóc okazać (p. 1 art. 198 KRU);

(c) rodzice są zobowiązani utrzymywać pełnoletnią córkę, syna, którzy kontynuują studia (art. 199 KRU);

(d) pełnoletnia córka oraz syn zobowiązani są utrzymywać rodziców, którzy nie są zdolni do pracy i potrzebują pomocy materialnej (p. 1 art. $202 \mathrm{KRU}$ ).

W taki sposób, w zakresie niemajątkowych i majątkowych praw i obowiązków matki, ojca i dziecka obserwujemy dosyć jawnie wyrażone i sformułowane normy, dzięki którym zasada pomocniczości może być zrealizowana w dostatecznej mierze.

Nie mniej ciekawie wygląda również sytuacja prawna zabezpieczenia dzieci-sierot i dzieci pozbawionych rodzicielskiej opieki. Ważnie jest, że Kodeks rodzinny Ukrainy przewiduje w rozdziale IV prostą logikę, która naszym zdaniem w całości odpowiada zasadzie pomocniczości - państwo nie bierze na siebie bezpośredniej odpowiedzialności za wychowanie dziecka, a tylko stwarza warunki, żeby nastąpiła realizacja jednej z następujących procedur:

1. adopcja (przysposobienie, usynowienie) (rozdz. $18 \mathrm{KRU})$;

2. kuratela i opieka nad dziećmi (rozdz. $19 \mathrm{KRU);}$

3. patronat nad dziećmi (rozdz. 2o KRU);

4. utworzenie rodziny zastępczej (rozdz. 20-21 KRU);

5. utworzenie domu dziecka typu rodzinnego (rozdz. 20-22 KRU).

Wszystkie wymienione wyżej instytucje są albo pełnowartościowymi rodzinami, albo quasi-rodzinami, w każdym razie są wspólnotami poziomu podstawowego. Zatem w ten sposób problem zabezpieczenia dzieci-sierot i dzieci pozbawionych rodzicielskiej 
opieki przechodzi od instytucjonalnego zabezpieczenia nadawanego wspólnotom poziomu wyższego do integracji we wspólnotę poziomu bazowego. Uważamy więc, że zasada pomocniczości realizuje się i w tym zakresie.

\section{Zasada pomocniczości w odniesieniu do dzieci i rodziny w kodeksach cywilnym i postępowania cywilnego Ukrainy}

W Kodeksie cywilnym Ukrainy (KCU) ${ }^{10}$ i Kodeksie postępowania cywilnego Ukrainy ${ }^{11}$ jako podstawowych dokumentach prawodawstwa cywilnego Ukrainy można znaleźć odniesienie do zasady pomocniczości co do dzieci i rodziny. Widać to wyraźnie w tych artykułach, w których mowa jest o zdolności do czynności prawnych osób fizycznych w wieku do 18 lat i odpowiedzialności za szkodę wyrządzoną przez dzieci.

Osoba fizyczna, zgodnie z KCU, nabywa zdolność prawną z chwilą narodzin, a w niektórych wypadkach, ustanowionych przez prawo, ochronie podlegają również interesy dziecka poczętego, ale jeszcze nienarodzonego. Natomiast zdolność do czynności prawnych zależy od wieku, stanu psychicznego i fizycznego. Dzieci mają ograniczoną zdolność do takich czynności.

Trudność polega na rozumieniu art. 32 KCU: „Zgoda na dokonywanie przez małoletnią osobę czynności prawnej powinna być

1 ЦЦивільний кодекс України (Kodeks cywilny Ukrainy) від 16 січня 2003 № 435-IV (Редакція від о6.11.2014), „Відомості Верховної Ради України (ВВР)”, 2003 р., № 40, ст. 356 (із змінами та доповненнями).

11 Цивільно-процесуальний кодекс Украӥни (Kodeks postępowania cywilnego Ukrainy) від 18 березня 2004 № 1618-IV (Редакція від о6.11.2014), „Відомості Верховної Ради України (ВВР)”, 2004 р., № 40, / 40-42 /, ст. 1530 (із змінами та доповненнями). 
otrzymana od rodziców (przysposabiających) albo kuratora i państwowego organu opieki i kurateli (z funkcjami podobnymi do funkcji sądu opiekuńczego w Polsce) zgodnie z prawem”. Dlatego też, jeśli przyjmuje się, że wystarczy tylko zgoda rodziców bez zgody organu opieki i kurateli (to znaczy zdanie należałoby rozumieć: albo zgoda rodziców, albo zgoda kuratora, który z kolei ma mieć zgodę organu opieki i kurateli), wówczas mamy do czynienia z zasadą pomocniczości (opartej na klasycznej instytucji prawa rzymskiego - pater familias $)^{12}$ co do rodziców. Do nich należy pierwszeństwo w opiece nad dzieckiem. Jeżeli zdanie przeczytamy w taki sposób: Zgoda [...] powinna być otrzymana od rodziców (przysposabiających) i organu opieki i kurateli albo kuratora i organu opieki i kurateli, wtedy o zasadzie pomocniczości nie może być mowy - widzimy tutaj, że istnieje prymat państwowych organów: w tym przypadku organu opieki i kurateli - wspólnot poziomu wyższego nad rodziną, czyli rodzicami i przysposabiającymi.

Godny uwagi jest p. 2 art. 35 KCU: „Pełną zdolność do czynności prawnych można uzyskać wskutek decyzji organu opieki i kurateli o zgłoszeniu zainteresowanej osoby za pisemną zgodą rodziców (przysposabiających) albo kuratora, a w razie, gdy takiej zgody nie ma, pełną zdolność do czynności prawnych można uzyskać wskutek decyzji sądu”. To potwierdza art. 242 KCPU, mówiąc, że „zgłoszenie niepełnoletniej osoby, która osiągnęła szesnaście lat, o uzyskaniu pełnej zdolności do czynności prawnych w wypadkach ustalonych przez KCU, w razie gdy nie ma zgody rodziców (przysposabiających) albo kuratora, wnosi pozew do sądu zgodnie z miejscem jej zamieszkania”. Tutaj można zobaczyć odstępstwo od zasady pomocniczości odnośnie do rodziny (rodziców, przysposabiających) jako jedynych

12 Д. р. Л. Мажец, Pater familias: Влада Отця людської родини (Pater familias: Władza Ojca rodziny ludzkiej) „Католицький Вісник” №9, Київ 2014, с. 2-3. 
w pełni odpowiedzialnych za dziecko, i uzurpację przez organy państwowe, w tym przypadku sąd i organ opieki i kurateli, tego, co należy do rodziców, i ich prawa do pełnej opieki nad dzieckiem.

KCU rozróżnia dwie kategorii dzieci: małoletnie - w wieku do 14 lat i niepełnoletnie - w wieku od 14 do 18 lat (art. 31, 33 KCU). Osoba małoletnia nie ponosi odpowiedzialności za wyrządzoną przez nią szkodę, a osoba niepełnoletnia - ponosi odpowiedzialność za wyrządzoną szkodę. Za szkodę wyrządzoną przez osobę małoletnią odpowiedzialność ponoszą rodzice (przysposabiający) albo kurator albo inna osoba fizyczna, która prawnie sprawuje opiekę nad osobą małoletnią (p. 1 art. 1178 KCU). Tak więc część pierwsza punktu 1 artykułu $1178 \mathrm{KCU}$ prezentuje zasadę pomocniczości, natomiast druga część tego samego artykułu mówi, że rodzice mogą tę zasadę ominąć i nie odpowiadać za szkodę wyrządzoną przez ich dziecko, jeśli udowodnią, „że szkoda nie jest skutkiem niesumiennego wypełnienia albo uchylenia się od wychowania i nadzoru nad osobą małoletnią" (p. 1 art. 1178 KCU).

Osoba niepełnoletnia zgodnie z art. 33 i art. 1179 KCU ponosi osobistą odpowiedzialność za wyrządzoną szkodę, czyli przestaje być dzieckiem i zasada pomocniczości w odniesieniu do niej przestaje działać w pełni, jak w przypadku osoby małoletniej. Artykuł 1179 KCU w p. 2 dla realizacji zasady pomocniczości zostawia tylko sytuację, kiedy majątek osoby niepełnoletniej nie wystarcza dla zadośćuczynienia. To samo dotyczy niepełnoletnich, którzy uzyskali pełną zdolność do czynności prawnych za zgodą rodziców według przepisów p. 2. art. 35 KCU.

\section{Zasada pomocniczości odnośnie do dzieci i rodziny w Kodeksie podatkowym Ukrainy}

Ponieważ zasada pomocniczości wymaga, aby rodzina i małżeństwo zrobiły wszystko, co potrzebne, aby w pierwszej kolejności samodzielnie zabezpieczyć swoją niezależność finansową, to 
odpowiednie gałęzie prawa - w tym rodzinne, fiskalne, budżetowe - muszą zabiezpieczyć do tego sprzyjające warunki ${ }^{13}$.

W takim kontekście na szczególną uwagę zasługuje podatek dochodowy od osób fizycznych. Uwzględnienie małżeńskich i małżeńsko-rodzinnych stosunków w ustawodawstwie fiskalnym Ukrainy przedstawiono w sposób bardzo ograniczony - Kodeks podatkowy Ukrainy ${ }^{14}$ prawie nie uwzględnia rodzinnego czy małżeńskiego statusu płacących podatek dochodowy od osób fizycznych (PIT - personal income tax). Każdy członek rodziny czy małżeństwa jest traktowany jak samodzielna osoba fizyczna i, odpowiednio, samodzielny podatnik. W poszczególnych wypadkach, takich jak nadanie rocznych kwot wolnych od podatku (tax credit) - p. 166.3 art. $166 \mathrm{KPU}$ - albo nadanie tak zwanej podatkowej socjalnej ulgi w ciągu roku (monthly tax credit) - art. $169 \mathrm{KPU}$ uwzględnia tych członków rodziny albo małżeństwa, którzy znajdują się na utrzymaniu podatnika.

Na przykład p. 169.1.2 art. 169 PKU ustala kwotę wolną od podatku (tax rebate) w rozmiarze 50 proc. minimalnego wynagrodzenia (minimum wage) na każde dziecko w wieku do 18 lat, które znajduje się na utrzymaniu podatnika. Jednocześnie ta sama norma ustala, że zaznaczona kwota stosuje się tylko wtedy, gdy podatnik ma dwoje lub więcej dzieci na utrzymaniu.

13 О. Браславець, Соціальне вчення Католицької Церкви в контексті сучасного суспільного розвитку (Nauka społeczna Kościoła Katolickiego w kontekście współczesnego rozwoju społecznego) „Актуальні Питання Соціально Значущої Діяльності Церков і Релігійних Організацій в Україні. Збірник Матеріалів" Київ 2004, с. 62-74.

14 Податковий кодекс України (Kodeks podatkowy Ukrainy) від 2 грудня 201 o p. № 2755-VI (Редакція від о8.1 1.2014), „Відомості Верховної Ради України (ВВР)", 2011 р., № 13-14, № 15-16, № 17, ст.112 (із змінами та доповненнями). 
W pp. (б) p. 169.1.3 art. 169 KPU ustalona jest podwyższona kwota wolna od podatku w rozmiarze 75 proc. minimalnego wynagrodzenia (minimum wage) na każde dziecko inwalidę w wieku do 18 lat, które znajduje się na utrzymaniu podatnika - bez ograniczenia liczby takich dzieci. W pp. (г) p. 169.1.3 w. 169 KPU jest analogiczna kwota dla dzieci, które samodzielnie otrzymują dochody i są oddzielnymi płatnikami podatku dochodowego od osób fizycznych, jeśli są oni uczniami albo studentami.

Jednak niektóre normy tego samego artykułu, szczególnie pp. (a) p. 169.1.3 art. 169 KPU, gwarantują kwoty wolne od podatku (tax rebate) $\mathrm{w}$ rozmiarze 75 proc. minimalnego wynagrodzenia odnośnie do dzieci tylko oddzielnych kategorii płatników. Chodzi o wdowy, wdowców, samotne matki i rodziców małoletnich dzieci bez ograniczenia liczby dzieci. Natomiast pełne rodziny i małżeństwa są pozbawione analogicznych ulg.

W art. 166 są przewidziane roczne ulgi podatkowe (tax credit) - kwoty, które są zwolnione od podatku według skutków rocznego deklarowania dochodów. W kontekście naszych rozważań interesujący jest p. 166.3.3 art. 166 PKU, który przewiduje nadanie ulgi podatnikowi, który spłaca na korzyść zakładów edukacji (na przykład uniwersytetów) koszty otrzymania średniego albo wyższego wykształcenia dla siebie albo członka swojej rodziny pierwszego stopnia pokrewieństwa, jeżeli ten jest na utrzymaniu. Dotyczy to również opłaty za nauczanie dzieci. Norma p. 166.3.4 KPU pozwala zwolnić od opodatkowania sumę pieniędzy spłaconych przez podatnika na korzyść zakładów lecznictwa, aby zrekompensować wartość płatnych usług leczenia samego podatnika i/albo członków jego rodziny pierwszego stopnia pokrewieństwa. W p. 166.3.5 KPU jest analogiczna norma dotycząca dobrowolnych wniosków do niepaństwowych funduszów ubezpieczeniowych tak za samego podatnika, jak i za członków jego rodziny pierwszego stopnia pokrewieństwa. 
Drugim podatkiem, który jest interesujący ze względu na temat badania, jest VAT (value-added tax). Zawiera on nadwyżkę do cen na towary, prace, usługi i jest ściągany w momencie wykorzystania już otrzymanych dochodów. Ukraińskie ustawodawstwo podatkowe, na przykład, w p. 197.1.1 art. 197 KPU zwalnia z VAT żywnościowe artykuły dziecięce i asortyment towarów dla dzieci; a zgodnie z p. 197.1.2 art. 197 KPU od VAT wolne są także koszty wydane na otrzymanie wyższego, średniego, zawodowego i przedszkolnego wykształcenia w placówkach edukacyjnych. Analogiczne podejście stosuje p. 197.1.5 co do usług z lecznictwa, a także p. 197.1.6 co do usług rehabilitacyjnych instytucji dla inwalidów i dzieci-inwalidów, w tym skierowania do sanatorium, i odpoczynek na terytorium Ukrainy dla dzieci w wieku do 18 lat i dzieci-inwalidów.

W ten sposób opisane normy pozwalają podatnikom, którzy mają dzieci, po wypełnieniu pewnych warunków albo (a) być zwolnionymi od opodatkowania pewnych części swoich dochodów i w taki sposób zwiększyć rozmiar czystej wypłaty zarobkowej, nie sięgając do otrzymania dodatkowych subwencji ze strony państwa; albo (b) obniżyć koszty na utrzymanie dzieci. W pewnych sytuacjach możemy twierdzić, że wspomniane normy są przykładem realizacji elementów zasady pomocniczości w ukraińskim ustawodawstwie fiskalnym.

\section{Zasada pomocniczości w odniesieniu do dzieci i rodziny w Kodeksie karnym i postępowania karnego Ukrainy}

Sprecyzowanej zasady pomocniczości nie znajdziemy w ukraińskim kodeksie karnym ${ }^{15}$, jak zresztą i w innych ukraińskich

15 Кримінальний кодекс України (Kodeks karny Ukrainy) від 5 квітня 2001 p. № 2341-III (Редакція від о1.01.2015), „Відомості Верховної Ради України (ВВР)", 2001, № 25, ст. 131 (із змінами та доповненнями). 
kodeksach prawnych. Dopiero niektóre przesłanki w normach KKU mogą wskazywać na dążenie jeśli nie do stworzenia definicji, to przynajmniej do realizacji tej zasady w odniesieniu do dzieci, małoletnich i rodziny.

Normy KKU otaczają troską wspólnoty poziomu podstawowego, rodziców, a zwłaszcza kobiety w ciąży i te, które mają dzieci do trzech lat, zapewniając im możliwość uzyskania w przypadku osadzenia w więzieniu warunkowo-przedterminowego zwolnienia (art. 83: Zwolnienie od odbywania kary dla kobiet w ciąży i kobiet, które mają dzieci w wieku do trzech lat).

Punkt 1 art. 83 mówi: „Skazane na ograniczenie wolności albo na pozbawienie wolności kobiety, które oczekują potomstwa albo narodziły dzieci podczas odbywania kary, oprócz skazanych na karę pozbawienia wolności na termin więcej niż pięć lat za umyślne ciężkie i szczególnie ciężkie przestępstwa, sąd może zwolnić od odbywania kary w granicach terminu, na który zgodnie z prawem (tj. prawo o pracy) kobieta może być zwolniona od pracy w związku z ciążą, porodami i do osiągnięcia wieku trzech lat przez dziecko”. Dalej p. 2 art. 83 mówi: „Zwolnienie od odbywania kary stosuje się do skazanej, która ma rodzinę albo krewnych, i tych, którzy zgodzili się na wspólny z nią pobyt, albo która ma możliwość samodzielnie zabezpieczyć odpowiednie warunki dla wychowania dziecka [...]", a p. 5 tego samego artykułu dodaje: „Jeśli skazana, która była zwolniona od odbywania kary, wypiera się dziecka, przekazała je do sierocińca, znikła z miejsca zamieszkiwania albo uchyla się od wychowania dziecka, opieki nad nim, albo systematycznie łamie prawo, co powoduje administracyjne sankcje i świadczy o zaniechaniu poprawy, sąd może po uzyskaniu informacji od kontrolującego organu skierować skazaną do odbywania kary przeznaczonej wyrokiem”. 
Naukowo-praktyczny komentarz do $\mathrm{KKU}^{16}$ wyjaśnia, że do rodziny, o której mowa w p. 2 art. 83 KKU, zalicza się: rodziców, małżeństwo, dzieci. Krewnymi zaś są: babcia, dziadek, rodzeństwo, wuj, ciocia, wnuki. Odpowiednie warunki dla wychowania dziecka to: posiadanie mieszkania, materialne możliwości dla zabezpieczenia wychowania i rozwoju dziecka, sprzyjające otoczenie rodzinne etc.

Przy tym daje się zauważyć, że KKU nie stwarza preferencji na przykład wobec ojców samotnie wychowujących dzieci. To stawia pod znakiem pytania prawidłowe rozumienie przez prawodawcę definicji rodziny, małżeństwa, potrzeby dziecka do posiadania obojga rodziców. Wygląda na to, że prawodawca widzi konieczność obecności matki dla dziecka, a jednocześnie nie widzi takiej potrzeby w odniesieniu do ojca.

Zgodnie z normami prawnymi KKU odpowiednim wiekiem dla odpowiedzialności karnej jest 16 lat, a odnośnie do niektórych przestępstw - 14 lat (art. $22 \mathrm{KKU})$. Osoba w wieku od 14 do 16 lat, która dokonała przestępstw, za które odpowiedzialność przewidziana jest od 16 roku życia, nie podlega odpowiedzialności karnej. Osoba w wieku od 14 do 18 lat jest uznana przez prawo karne Ukrainy za niepełnoletnią. Niektóre kwestie dotyczące dzieci i rodziny bardziej szczegółowo są omówione w Kodeksie postępowania karnego Ukrainy ${ }^{17}$. Wyrazem troski o dzieci jest ograniczenie spisu

16 Кримінальний кодекс Украӥни: Науково-практичний коментар (Коdeks karny Ukrainy: Komentarz naukowo-praktyczny), За заг. ред. В. В. Сташиса, В. Я. Тація, Харків 2006, с. 1184.

17 Кримінально-процесуальний кодекс України (Kodeks postępowania karnego Ukrainy) 13 квітня 2012 р. № 4651-VI (Редакція від 26.10.2014), „Відомості Верховної Ради України (ВВР)” 2013, № 9-10, ст. 474 (із змінами та доповненнями). 
przestępstw, za które przewidziano odpowiedzialność dla niepełnoletnich w wieku od 14 do 16 lat. W przypadku kiedy dokładne wyznaczenie wieku osoby nie jest możliwe i eksperci są w stanie ustalić tylko rok, KPK Ukrainy nakazuje brać pod uwagę ostatni dzień roku wyznaczonego przez ekspertów. W sytuacji kiedy wiek osoby wylicza się w pewnych ramach (między 14 a 15 rokiem życia, między 15 a 17 rokiem życia), Kodeks postępowania karnego Ukrainy nakazuje obliczać wiek osoby wychodząc z minimalnego w tych ramach wieku (art. 89 KPKU).

Oprócz tego w czasie postępowania karnego, w tym podczas postępowania co do stosowania przymusowych środków wychowawczych, śledczy, prokurator, śledczy sędzia, sąd i inne osoby, które biorą w nim udział, są zobowiązani spełniać działania procesualne w takim trybie, który najmniej narusza zwyczajny układ życia niepełnoletniego, biorąc pod uwagę jego wiek i psychikę; wyjaśniać treść działań procesualnych, decyzji i ich znaczenia, wysłuchiwać jego argumentów przy podejmowaniu decyzji procesualnych i używać wszystkich innych środków, skierowanych na unikanie negatywnego wpływu na niepełnoletniego (art. $484 \mathrm{KPKU})$.

KPKU w p. 1. art. 488 mówi o uczestnictwie rodziców i innych prawnych opiekunów niepełnoletniego podejrzanego czy oskarżonego. Ale już p. 2 art. 488 wyjaśnia, że prawni opiekunowie są powoływani na sądowe obrady, ale ich nieprzybycie, oprócz przypadków, kiedy sąd uznaje ich obecność za niezbędną, nie zatrzymuje prowadzenia sądowego. W kolejnym punkcie art. 488 KPKU ustala się, że: „w wyjątkowych wypadkach, kiedy uczestnictwo prawnego przedstawiciela może wyrządzić szkody interesom niepełnoletniego podejrzanego czy oskarżonego, sąd za jego podaniem, podaniem prokuratora czy z własnej inicjatywy swoją uchwałą ma prawo ograniczyć uczestnictwo prawnego przedstawiciela w wykonaniu oddzielnych procesualnych czy sądowych 
czynności albo usunąć jego od uczestnictwa w postępowaniu karnym i wezwać zamiast niego innego prawnego przedstawiciela" (p. 3 art. $488 \mathrm{KPKU}$ ).

Uważamy, że taka kolejność zdań jest nieprawidłowa, ponieważ ze względu na rodziców jako wspólnotę podstawową właśnie oni w pierwszej kolejności są zobowiązani do uczestnictwa w obradach sądu, a ich nieprzybycie ma doprowadzić do uniemożliwienia prowadzenia dalej procesu sądowego i wyjaśnienia okoliczności, które spowodowały ich nieprzybycie. I tylko w tych wyjątkowych sytuacjach (kiedy uczestnictwo prawnego przedstawiciela może wyrządzić szkody interesom niepełnoletniego), sąd na prośbę samego niepełnoletniego, prokuratora czy sam z własnej inicjatywy swoją uchwałą ma prawo ograniczyć uczestnictwo prawnego przedstawiciela (rodziców) w wykonaniu oddzielnych procesualnych czy sądowych czynności albo może usunąć go od uczestnictwa w prowadzeniu sprawy sądowej i włączyć do postępowania prawnego innego prawnego przedstawiciela.

\section{Wnioski}

Biorąc pod uwagę rozpatrzoną przez nas część korpusu ustawodawstwa ukraińskiego, możemy wyciągnąć kilka ważnych wniosków. Po pierwsze, ustawodawstwo ukraińskie wyróżnia zasadę pomocniczości i czasami korzysta z niej zarówno z pozycji prawnej formy, jak i zgodnie z treścią. Jednak temu procesowi brakuje systematyczności - naszym zdaniem świadczy to o tym, że uświadomienie tej zasady ukraińskiemu społeczeństwu i ustawodawstwu przebywa w stadium początkowym i dopiero się rozwija.

Po drugie, w samej konstrukcji rozpatrzonego korpusu prawnego daje się zauważyć kilka kompleksowych systemowych przeciwieństw, zarówno pomiędzy oddzielnymi aktami prawnymi, jak i między artykułami jednego i tego samego aktu prawnego. Przykładem takiej fundamentalnej wewnętrznej sprzeczności 
ustawodawstwa ukraińskiego może służyć Konstytucja Ukrainy, w której część norm zakłada podstawę dla realizacji zasady pomocniczości, lecz istnieje inna część norm, omijających poziom wspólnot podstawowych czy struktur pośrednich, gdzie państwo udziela odpowiednich uprawnień. Taki wewnętrzny konstytucyjny dysonans doprowadza do zwiększenia kontrowersji wśród KCU i KKU, KCU i KRU, KRU i KPU i tym podobnych.

Po trzecie, z punktu widzenia chronologii uchwały aktów prawodawczych możemy wyraźnie wydzielić trzy bloki, gdzie w ustawodawstwie ukraińskim obserwuje się różne tendencje przyzwalające na zasadę pomocniczości w odniesieniu do dzieci i rodzin. Pierwszy okres - połowa lat 9o. XX wieku, to czas uchwalenie nowej ukraińskiej Konstytucji (1996). Drugi okres - początek XXI wieku, kiedy był uchwalony Kodeks karny Ukrainy (2001), Kodeks rodzinny Ukrainy (2002), Kodeks cywilny Ukrainy (2003), Kodeks cywilno-procesowy Ukrainy (2004). Jak pokazała analiza, właśnie ten okres był najbardziej produkcyjny i progresywny w kwestii zastosowania i wdrożenia zasady pomocniczości w ustawodawstwie ukraińskim. Trzeci okres - okres po 2010 roku, kiedy uchwalone zostały kodeksy podatkowy i budżetowy Ukrainy (oba w 2010 roku). Uważamy, że analiza działalności ustawodawczej na tle innych społeczno-politycznych przekształceń i procesów pozwala twierdzić, że zmiana podejścia do zasady pomocniczości ma charakter koniunkturalny i w żaden sposób nie jest związana z systemowymi i strukturalnymi reformami prawa ukraińskiego.

Po czwarte, odnośnie do realizacji zasady pomocniczości w normach prawnych ustawodawstwa ukraińskiego, dotyczących rodziny i dzieci, uważamy, że ważnym kierunkiem reform prawnych we wspomnianym zakresie jest uznanie - najpierw na poziomie ustawodawczym, później w stosowaniu przepisów prawnych - ważnej roli wspólnot poziomu podstawowego i struktur pośrednich. Pozytywna tendencja jest do zaobserwowania w takich gałęziach 
prawa jak prawo rodzinne i proces karny, lecz słabo uwidacznia się w cywilnym; praktycznie jest nieobecna w prawie podatkowym i budżetowym.

Po piąte, na poziomie prawnego paradygmatu niemal nieuchwytne jest podejście, kiedy w całości ignoruje się istnienie władczych uprawnień rodziny i pater familias, chociaż właśnie ta instytucja prawa rzymskiego naszym zdaniem jest podstawą zasady pomocniczości stosownie do dzieci i rodziny.

Uważamy, że na mówienie o gotowości ukraińskiego systemu prawnego do użycia w praktyce prawnej zasady pomocniczości jest jeszcze za wcześnie. Dzisiaj nagląca jest konieczność społecznego uświadomienia sobie i omówienia tej problematyki, kształtowanie prawnych paradygmatów i koncepcji oraz stopniowego wprowadzenia odpowiednich korygujących zmian do czynnego ustawodawstwa Ukrainy.

SUMMARY

\section{Realization of the principle of subsidiarity in norms from Ukrainian legislation about family and children}

Family community, among many other communities, is essential for the formation of the child and protection of fundamental rights.

During 1991-2013 Ukraine formed a paternalistic type of social structure. As a result, an essential part of society - family - lost its social role and has been deprived of its basic functions.

This article analyzes the Constitution of Ukraine, Ukrainian Family, Civil, Tax, and Criminal Codes for compliance of their rules affecting children and families with the principle of subsidiarity as it is understood by the social doctrine of the Catholic Church. 
The study revealed that Ukrainian legislation lacks a clear definition of the principle of subsidiarity. Nonetheless, the content of analyzed laws indicates that the understanding of the principle of subsidiarity arises in Ukrainian society, and this principle is gradually implemented in Ukrainian law.

Keywords: principle of subsidiarity, Ukrainian law, legal status of family and child, basic social community, Constitution of Ukraine, Tax Code, Criminal Code, Civil Code, Family Code, financial autonomy, privilege

Oleksii Braslavets, Viktoriya Semenova, Realizacja zasady pomocniczości w normach prawnych ustawodawstwa ukraińskiego dotyczących rodziny i dzieci, [w:] Prawa dziecka: perspektywa Kościoła, red. ks. Piotr Kroczek, Kraków 2015, s. 153-174 (Annales Canonici Monographiae, 3).

DOI: http://dx.doi.org/10.15633/9788374384353.09 